\title{
From Neo-Slavism to Internationalism: Interwar Central Europe and the Search for the Lost Mountains
}

\author{
Carolin F. Roeder \\ Max Planck Institute of the History of Science, Boltzmannstraße 22, 14195 Berlin, Germany \\ croeder@mpiwg-berlin.mpg.de
}

\begin{abstract}
This article highlights the contribution of East Central Europe to interwar internationalism by showing how solutions to regional challenges gave birth to the Union internationale des associations d'alpinisme (UIAA), a permanent international organisation for mountaineering. The territorial fragmentation caused by the dissolution of the Habsburg Empire required alpine clubs to lobby for the softening of new political borders while simultaneously contributing to state building efforts. Successful experiences with bilateral agreements in the Tatras and re-emerging Neo-Slavist ideas led to the founding of the Association of Slavic Tourist Organization in 1924, which in turn motivated the establishment of the UIAA. The leading figures in this process were alpinists with a distinct internationalist profile who navigated seamlessly between their role as agents of the state and private citizens.
\end{abstract}

In August 1932 representatives from almost fifty alpine, tourist and ski clubs hailing from twenty countries convened at the Third International Alpine Congress in the French town of Chamonix-Mont-Blanc. At a moment when international institutions proliferated, the time had come to finalise an idea that had been formulated already in the previous century: the founding of an international organisation of mountaineering. ${ }^{1}$ Large societies active in the Alps had sent their delegates to meet with organisations from overseas, including the American Alpine Club and its Canadian counterpart. But representatives of smaller countries were also present, including those that had only gained independent statehood after the First World War: Yugoslavia, Hungary, Czechoslovakia and Poland. While these states were of recent creation, their clubs were founded in the second half of the nineteenth century when alpine associations dedicated to the pursuit of mountain tourism and sports emerged all over Europe and the Western hemisphere. ${ }^{2}$

The cordial atmosphere of the congress was briefly disturbed when a dispute arose between a member of the Polish Tatra Society and his colleague from Czechoslovakia. A British delegate observed

\footnotetext{
1 M.J. Marchandise, ed., Congrès international d'alpinisme Chamonix Mont-Blanc 1932: Rapports et travaux du Congrès (Paris: Club Alpin Français, 1932), 5-7. For the proliferation of international institutions in the interwar period, the most prominent of them being the League of Nations, see Akira Iriye, Cultural Internationalism and World Order (Baltimore: Johns Hopkins University Press, 1997), 20-1.

2 In the course of the nineteenth century, the term alpinism (mountaineering) came to refer to a practice independent of geographical location. The term alpine club serves as shorthand for associations dedicated to the touristic use of mountains, which can include alpinism but also non-technical hiking. For the beginnings of alpine tourism see, for example, Susan Barton, Healthy Living in the Alps: The Origins of Winter Tourism in Switzerland, 1860-1914 (Manchester: Manchester University Press, 2008); Andrew Denning, Skiing into Modernity: A Cultural and Environmental History (Oakland, California: University of California Press, 2015); Jim Ring, How the English Made the Alps (London: John Murray, 2000); Laurent Tissot, 'From Alpine Tourism to the 'Alpinization' of Tourism', in Eric G. E. Zuelow, ed., Touring beyond the Nation: A Transnational Approach to European Tourism (Farnham, Surrey: Ashgate, 2011).

(C) The Author(s) 2019. This is an Open Access article, distributed under the terms of the Creative Commons Attribution licence (http://creativecommons.org/licenses/by/4.0/), which permits unrestricted re-use, distribution, and reproduction in any medium, provided the original work is properly cited.
} 
the altercation. According to his account, the 'chief delegate of yet another new republic - represented at the gathering by no fewer than fourteen official members - asserted that a certain "mountain" poet of his nationality was greater by far than any other, including Shakespeare or Goethe'. The British alpinist claimed that none of the bystanders contested this statement, 'since no one was present able to understand the language of the said poet' [sic], adding in a caustic footnote: 'name unpronounceable - spelling indecipherable'. He continued: 'the further statement by the selfsame delegate, that the Tatra belonged geologically to his country, was, however, denied indignantly by the representatives of the other new republic owning the southern slopes. Both delegates produced intestinallooking maps to prove their claims. ${ }^{3}$

The condescending tone of the alpinist flagrantly displayed British chauvinism towards the newly independent states. His statement projected a hierarchy of European nations in which the new states, the names of which he did not care to mention, occupied a place at the margins. His demeaning footnote underlined a point Milan Kundera made in the 1980s, when he wrote in a famous essay of the 'curtain of their strange and scarcely accessible languages' that inhibited the full integration of East Central Europe into the wider consciousness of Europe. ${ }^{4}$ Yet the arrogance of the British delegate was misplaced. Perhaps he did not know better, but if it was not for the Polish Tatra Society, in particular the 'chief delegate' Walery Goetel, there would have been no congress in Chamonix and thus no resolution to establish the Union internationale des associations d'alpinisme (UIAA), a permanent international organisation of alpine clubs, since its inception was owed to the cultural, political and geographical legacies of the Habsburg Empire. As this article will demonstrate, East Central Europeans were agents of internationalism in their own right and skilfully used their regional experience for pursuing a larger international agenda.

In fact, it was the very conflict over the 'intestinal-looking maps' of the Tatra mountains that played a crucial part in this process. Once the Habsburg Empire was no more, new international borders restricted the mobility of tourists and mountaineers across Central Europe. In the early 1920s a joint Czech-Polish initiative to solve territorial disputes in the High Tatras had set a precedent of cross-border cooperation between alpine clubs in an effort to deal with the loss of the Carpathian Mountains as a shared imperial space. This cooperation spurred the founding of the Association of Slavic Tourist Societies in 1925, which in turn originated in a short-lived ideological movement of the pre-war era aimed at promoting solidarity and equality among all Slavic nations: Neo-Slavism. Preceded by congresses in the Polish mountain town of Zakopane and Budapest in 1930 and 1931 respectively, Chamonix and the establishment of the UIAA was the culmination of East Central European alpine clubs to broaden the geographical framework of cooperation and lobby for an international mountaineering organisation that promised a way to secure access to mountains in a fragmented Europe.

Perhaps we should be lenient with the ostensibly ignorant British alpinist - it is indeed surprising that the roots of an international organisation for alpinism are to be found in East Central Europe. Mountaineers from Poland, a country whose toponym hints to its flatness, seemed improbable promoters of an international mountaineering organisation. ${ }^{5}$ Hungary, a state completely deprived of high mountains, was likewise an unlikely place to hold an International Alpine Congress. Leaving aside topography, not only contemporary but also current historiographical work on internationalism has largely marginalised the role of East Central Europeans in interwar internationalism. Only very recently has historiographical work emerged that departs from the Western-centric approach to the

\footnotetext{
3 'Alpine Notes: III ${ }^{\mathrm{e}}$ Congrès international d'alpinisme', Alpine Journal, 44 (1932), 342. The incident was so memorable that ten years later, the Alpine Club's vice president, Sidney Spencer, recounted the episode in a letter to someone who inquired about the fate of the UIAA (Union internationale des associations d'alpinisme). Sidney Spencer to Donkin, 18 Sept. 1943, 1922/B4/25, Alpine Club, London.

4 Milan Kundera, 'The Tragedy of Central Europe', New York Review of Books, 31, 7 (1984). In the context of this article, East Central Europe excludes Germany and Austria and includes Yugoslavia and Bulgaria.

5 Poland (pl. Polska) contains the early Slavic root pole (field).
} 
history of internationalism in Europe. ${ }^{6}$ This article expands the scope of this work to a realm of internationalism that was closely linked to geopolitical questions and geared towards establishing an international organisation that would, among others, alleviate travel restrictions for mountain enthusiasts across state borders. In reconstructing the regional origins of the UIAA, this article draws attention to the productive cultural and political forces of the former Habsburg space, which in the light of the myriad challenges the new countries faced have long been overlooked.

As the introductory anecdote revealed, finding internationalist solutions to the problem of lost mountain spaces in the midst of nation building projects was not without tensions. The paradox that the promoters of internationalism, in this case the representatives of the Czechoslovak and Polish alpine clubs, were also staunch nationalists underlines the intrinsic relationship of those two ideals in the interwar period. While recent work on internationalism has duly recognised the linkage between internationalism and nationalism, this relationship was even more marked if the area of interest concerned geopolitical questions. ${ }^{7}$ Defending the Polish character of the Tatras while also promoting an international organisation tasked to work towards the breaking down of impenetrable national borders was thus not a contradiction in itself but rather the essence of interwar internationalism, as illustrated by Walery Goetel's personal example: he was both a staunch promoter of Poland and a reputable figure in the realm of internationalism. ${ }^{8}$ In a similar vein Hungary's involvement in alpine internationalism, originally a project of the neighbouring Slavic states, reveals the intricate link between politics of territorial revisionism and strategies of internationalism.

In order to trace the impact of political and cultural legacies on new forms of internationalism across major political ruptures, it is worth considering internationalism in a broader diachronic framework of European history. Taking the period before 1918 into consideration reveals continuities of transnational connections but also changes of agendas and actors. In the specific case of East Central Europe, another question is at stake: that of imperial legacies in the Habsburg successor states

${ }^{6}$ Despite its impressive scope, Glenda Sluga's and Patricia Clavin's important edited volume contains only one contribution addressing East Central Europe, though in the post-war era, Sandrine Kott, 'Cold War Internationalism', in Glenda Sluga and Patricia Clavin, eds., Internationalisms: A Twentieth-Century History (Cambridge, UK: Cambridge University Press, 2016). While there is a rising interest in socialist internationalism in the Cold War era, the works on interwar East Central Europe are far and few in between, including for example Katharina Kreuder-Sonnen, 'From Transnationalism to Olympic Internationalism: Polish Medical Experts and International Scientific Exchange, 1885-1939', Contemporary European History, 25, 2 (2016), 207-31; Daniel Laqua, 'Exhibiting, Encountering and Studying Music in Interwar Europe: Between National and International Community', European Studies: A Journal of European Culture, 32, 1 (2014), $207-$ 23; Katrin Steffen and Martin Kohlrausch, 'The Limits and Merits of Internationalism: Experts, the State and the International Community in Poland in the First Half of the Twentieth Century', European Review of History: Revue européenne d'histoire, 16, 5 (2009), 715-37; Katrin Steffen, 'Experts and the Modernization of the Nation: The Arena of Public Health in Poland in the First Half of the Twentieth Century', Jahrbücher für Geschichte Osteuropas, 61, 4 (2013), 574-90. On this gap see also Jessica Reinisch, 'Introduction: Agents of Internationalism', Contemporary European History, 25, 2 (2016), 204-05.

7 On the relation of nationalism and internationalism, see in particular Glenda Sluga, Internationalism in the Age of Nationalism (Philadelphia: University of Pennsylvania Press, 2013). See also the contributions to Daniel Laqua, ed. Internationalism Reconfigured: Transnational Ideas and Movements between the World Wars (London: I.B. Tauris, 2011).

8 On the importance of internationalism for interwar East Central European nationalism see Laqua, 'Exhibiting, Encountering and Studying Music in Interwar Europe'; Andrea Orzoff, Battle for the Castle: The Myth of Czechoslovakia in Europe, 1914-1948 (New York: Oxford University Press, 2009); Daniel Laqua, 'Internationalism and Nationalism in the League of Nations' Work for Intellectual Cooperation', in Miguel Bandeira Jerónimo and José Pedro Monteiro, eds., Internationalism, Imperialism and the Formation of the Contemporary World: The Pasts of the Present (Cham: Springer International Publishing, 2018), 59-85. On interwar internationalism see also Iriye, Cultural Internationalism and World Order. On Walery Goetel's involvement in international nature protection see Anna-Katharina Wöbse, Weltnaturschutz: Umweltdiplomatie in Völkerbund und Vereinten Nationen 1920-1950 (Frankfurt a.M.: Campus, 2012), 266. On his political positions regarding a planned binational park in the Tatras see in detail Bianca Hoenig, Geteilte Berge: Eine Konfliktgeschichte der Naturnutzung in der Tatra (Göttingen: Vandenhoeck \& Ruprecht, 2017). 
after 1918, which has recently begun to receive growing scholarly attention. ${ }^{9}$ Likewise, locating the beginnings of European cooperation in the interwar period questions the conception of 1945 and the decade after as an 'hour zero', as Kiran Klaus Patel and Wolfram Kaiser have recently highlighted. ${ }^{10}$ Accordingly, the first part of this article will introduce 'celebratory' alpine internationalism as it was practiced until 1920: this form of internationalism remained limited to quasi-scientific congresses that despite their scientific claims largely appealed through social events such as excursions and lavish celebrations. Moving into the 1920s and late 1930s, the article will then discuss how under the aegis of East Central European actors, this celebratory alpine internationalism shifted towards a more governance-oriented approach that addressed looming questions of the twentieth century such as political borders and environmental protection of mountain regions in the framework of a permanent international organisation for mountaineering. The audience, scope and aims of the organisation were highly specialised, and hence could be described as 'boutique' internationalism that was pragmatic and did not claim the same universalism as other kinds of internationalism. Yet it was effective in particular on an interpersonal level. ${ }^{11}$ Despite the founding of the UIAA at the eve of political turmoil in East Central Europe and its limited interwar achievements, the organisation's founders achieved to create long-lasting networks which endured into the post-Second World War era and remained resilient in a bifurcated Cold War Europe.

\section{From Celebratory Alpine Internationalism to an Alpinist Versailles}

Since the mid-nineteenth century, non-governmental alpine clubs have shaped not only cultural imaginations and valuations of the Alps and other mountain ranges, but also their physical environment and local economies by promoting mountain tourism, financing infrastructure, mapping and constructing extensive webs of trails and huts. Moreover, alpine clubs also played a crucial role in the nation building processes of Central Europe. While recent work, in particular on the German and Austrian Alpine Club, has put much emphasis on alpine clubs as national agitators, this story is only part of the picture. ${ }^{12}$ Alpine clubs were also engaged in transnational exchanges and took part in the age of internationalism which coincided with their emergence in the latter half of the nineteenth century. Called into life by international scientific communities, this new period was driven by efforts

\footnotetext{
9 See Tim Buchen and Frank Grelka, eds., Akteure der Neuordnung. Ostmitteleuropa und das Erbe der Imperien, 1917-1924 (Berlin: epubli, 2016); Paul Miller and Claire Morelon, eds., Embers of Empire: Continuity and Rupture in the Habsburg Successor States after 1918 (New York: Berghahn, 2018). Crucial to the discussions about the Habsburg legacy is the rethinking of the end of empire, see in particular the work of Pieter Judson, for example The Habsburg Empire: A New History (The Belknap Press of Harvard University Press, 2016); 'Where our commonality is necessary...': Rethinking the End of the Habsburg Monarchy', Austrian History Yearbook, 48 (2017), 1-21.

10 Kiran Klaus Patel and Wolfram Kaiser, 'Continuity and Change in European Cooperation during the Twentieth Century', Contemporary European History, 27, 2 (2018), 168-69.

11 See Glenda Sluga and Patricia Clavin, eds., Internationalisms: A Twentieth-Century History (Cambridge, UK: Cambridge University Press, 2016).

12 On the German and Austrian Alpine Club see, for example, Tait Keller, Apostles of the Alps: Mountaineering and Nation Building in Germany and Austria, 1860-1939 (Chapel Hill: The University of North Carolina Press, 2016). On the Slovenian Alpine Club, nationalism and mountains as national symbols see Boštjan Šaver, Nazaj v planinski raj: alpska kultura slovenstva in mitologija Triglava (Ljubljana: Fakultet za družbene vede, 2005); Carolin F. Roeder, 'Slovenia's Triglav National Park: From Imperial Borderland to National Ethnoscape', in Bernhard Gissibl, Sabine Höhler and Patrick Kupper, eds., Civilizing Nature: National Parks in Global Historical Perspective (New York: 2012), 240-55. On Italy see Marco Armiero, Rugged Nation: Mountains and the Making of Modern Italy (Cambridge: White Horse, 2011). On Switzerland see Oliver Zimmer, 'In Search of Natural Identity: Alpine Landscape and the Reconstruction of the Swiss Nation', Comparative Studies in Society and History 40, 4 (1998), 637-65. For a general discussion on mountains and the nation state see Bernard Debarbieux and Gilles Rudaz, The Mountain: A Political History from the Enlightenment to the Present (Chicago: University of Chicago Press, 2015), 88-113.
} 
to codify and standardise data, measurements and regulations. ${ }^{13}$ At the same time, international sports organisations started to form. ${ }^{14}$ Conceived as promoters of knowledge about the Alps as well as their leisurely enjoyment, alpine clubs emerged as important facilitators of transnational knowledge dissemination and served as the institutional foundation for both real and imagined communities of hundreds of thousands of middle-class (and some working-class) citizens in Europe and beyond who spent leisure time in the mountains as casual hikers, skilled climbers and mountaineers or simply as vacationers. ${ }^{15}$

The global community of mountaineers was sustained by an extraordinarily rich printing culture a republic of journals, as one could call it. However, the new spatial reality was not only created through reproducible nature disseminated via periodicals, journals and books, new cartographic discourses and the promotion of tourism, but also in form of international congresses. ${ }^{16}$ These congresses, modelled on international scientific congresses of learned societies, constituted the most visible expression of alpine internationalism and a first attempt to understand and promote mountain spaces on a non-governmental international level. ${ }^{17}$ In 1876 , only two years after its founding, the French Alpine Club (Club Alpin Français; CAF) invited all European alpine clubs to a three-day long International Alpine Congress in Annecy. Excursions, lectures and social events entertained participants from France, Italy, Switzerland and the United Kingdom. The French were latecomers in the realm of alpinism and could not boast of any first ascents in the Alps; lavish celebrations thus offered an opportunity to showcase their sophisticated contribution to the Belle Epoque. ${ }^{18}$

In this vein, a 'Fête internationale' followed in 1877 in Grenoble, the capital of the French Alps, during which over three hundred guests spent four days enjoying social gatherings, excursion and scientific lectures devoted to general questions regarding mountains. ${ }^{19}$ At a subsequent international meeting in Gressoney in August 1877, the alpine clubs agreed that henceforward one annual congress should be organised successively by the French, Italian, Swiss and German-Austrian clubs. ${ }^{20}$ Furthermore, a plan was made to prepare an 'international treaty' that would 'tighten more and more the brotherly bonds between the alpine clubs. ${ }^{21}$ Although a series of congresses followed in Paris (1878), Geneva (1879), Salzburg (1882) and Turin (1885), no commitment to an institutionalisation of alpine internationalism as suggested in Gressoney was made. This was not least due to the resistance of the German and Austrian Alpine Club (Deutscher und Oesterreichischer Alpenverein; DOeAV), which refused to support any international statute that would be of a binding nature. As the largest alpine association which spanned both the German Reich and the Habsburg Empire,

13 On scientific internationalism see, for example, Mark Mazower, Governing the World: The History of an Idea (New York: Penguin, 2012), 101-4; Davide Rodogno, Bernhard Struck and Jakob Vogel, eds., Shaping the Transnational Sphere: Experts, Networks and Issues from the 1840s to the 1930s (Oxford: Berghahn, 2016).

14 On sports organisations, see Barbara Keys, Globalizing Sport: National Rivalry and International Community in the 1930s (Cambridge, MA: Harvard University Press, 2006).

15 While some clubs, such as the (British) Alpine Club, were focused only on technical mountaineering, the overwhelming number of clubs included also 'tourism' in the portfolio, a term which in this context refers to an active form of tourist, including hiking. For details on alpine tourism, see Tissot, 'From Alpine Tourism to the 'Alpinization' of Tourism'.

16 For spatial realities, see Benedict Anderson, Imagined Communities: Reflections on the Origin and Spread of Nationalism, rev. edn (London: Verso, 2006).

17 On international scientific congresses, see Paul Servais, 'Scholarly Networks and International Congresses: The Orientalists before the First World War,' in W. Boyd Rayward, ed., Information beyond Borders: International Cultural and Intellectual Exchange in the Belle Époque (Farnham: Ashgate, 2014), 85-95. On the globalisation of mountain issues in the twentieth century see Debarbieux and Rudaz, The Mountain, 193-242.

18 François Descostes, Trois jours en Savoie: Congrès des clubs alpins à Annecy (août 1876) (Annecy: Perrissin, 1877), 49. For the French Alpine Club in the Belle Époque see Olivier Hoibian, 'Le Club Alpin Français (1874-1914)', in Olivier Hoibian, ed., L'invention de l'alpinisme: La montagne et l'affirmation de la bourgeoisie cultivée, 1786-1914 (Paris: Belin, 2008$), 256$.

19 'Deuxième Congrès du Club alpin français et Fêtes internationales a Grenoble, en août 1877', GA SAC 291, 15-9, Burgerbibliothek, Berne.

20 A.B. Hamilton, 'The Fête of the French Alpine Club at Grenoble in 1877', Alpine Journal, 8 (1878), 446. The (British) Alpine Club was given the opportunity to organise a congress if it wished to do so.

21 Descostes, Trois jours en Savoie, 49. 
the club saw little incentive in submitting to any kind of international organisation. ${ }^{22}$ Within the French Alpine Club, the enthusiasm for congresses died down as well. In 1900 the last International Alpine Congress before the war was held in Paris in conjunction with the World's Fair and the Summer Olympics.

During the First World War, the political polarisation reinvigorated internationalist ideas among European and North American mountaineers. ${ }^{23}$ In early 1917, when hopes were high that the war would not last for much longer, mountaineers envisioned a congress 'beneath the entwined national banners of the victorious Allies' after 'the common enemy [had been] crushed'. ${ }^{24}$ Three months after the diplomats and delegates had left the Paris Peace Conference, the alpine clubs of the Allied and neutral countries met for their own version of post-war conference in Monaco on the French Riviera. The relations between Europe's alpine clubs resembled a microcosm of interwar politics. The congress was conceived as a celebration of the Allied victory and provided an opportunity to reunite mountaineers from around the globe - with the explicit exclusion of the war enemies. Just as in other realms of transnational relations, most prominently in the scientific realm, the former Central Powers were excluded from the early reconstitution of international exchange.

The proceedings of the congress in Monaco spoke of the seriousness of the eight-day long endeavour. Almost one-thousand pages long, the two volumes included not only the scientific and semi-scientific papers given at the congress but also detailed information about the activities of the participating clubs - ranging from the Japanese Alpine Club to the Sagebrush and Pine Club, a local organisation from Washington State. ${ }^{25}$ Yet, although the congress showcased loyalty among the prestigious alpine clubs and symbolically reinvigorated post-war mountaineering, the delegates made no commitment to continuing or institutionalising further international cooperation. The British, devoted to institutionalising sport but traditionally sceptical towards the notion alpinism should be an aid to science, even attended the congress mainly to 'show a good feeling towards the French, if nothing else', and, although wary of overeating and over drinking, enjoy themselves. ${ }^{26}$ As mountaineering oscillated between science, sport and tourism, it was not clear in which direction alpine internationalism would develop. Neither the French Alpine Club nor any other Western European association organised a lavish international congress in the decade to come. Thus, Monaco 1920 was the final expression of celebratory internationalism among alpine clubs.

\section{Searching for the Lost Mountains: Interwar East Central Europe}

The congress at Monaco might have been conceived as an alpinist Versailles, yet the desires of the attendees focused on high mountains rather than the new post-war order: slide shows of the Canadian Rockies, the Himalayas and the Japanese Alps were able to lure more participants into

\footnotetext{
22 'Bericht über den IV. internationalen alpinen Congress am 12. und 13. August 1882 und über die neunte General-Versammlung', Zeitschrift des Deutschen und Oesterreichischen Alpenvereins (1882), 451-2. The reluctance of the leaders of the German-Austrian Alpine Club to go any further than participating in international congresses was particularly clearly expressed in the closing speech of the 1882 Salzburg Congress. President Barth applauded international cooperation while at the same time communicating that he regarded calls for a permanent organisation as unattainable (or undesirable) ideals.

23 The initiative came from the president of the French Alpine Club, Baron Gabet, who was determined to revive the role of the club as the leading organiser of international alpine gatherings. For the revival of internationalism after the First World War, see Akira Iriye, Global Community: The Role of International Organizations in the Making of the Contemporary World (Berkeley: University of California Press, 2002).

24 Gabet to Alpine Club, 21 Jan. 1917; for 'common enemy' see John D. Patterson to Gabet, 23 Jan. 1918, F14 Alpine Congress Monaco, Alpine Club, London. Members of alpine clubs from following countries were present: France, the United Kingdom, Canada, the United States, South Africa, New Zealand, Italy, Spain and Japan.

25 Maurice Pailion, ed. Congrès de l'alpinisme: Comptes Rendus, vol. 1 (Paris: 1921).

26 'Le Congrès de l'alpinisme à Monaco $1^{\text {er }}$ Mai-20 Mai 1920', Alpine Journal, 33 (1921), 250. For the motivations to attend see Farrar to J.E.C. Eaton, 20 Mar. 1919, 1922/F14 Alpine Congress 1920 Monaco, Alpine Club, London.
} 


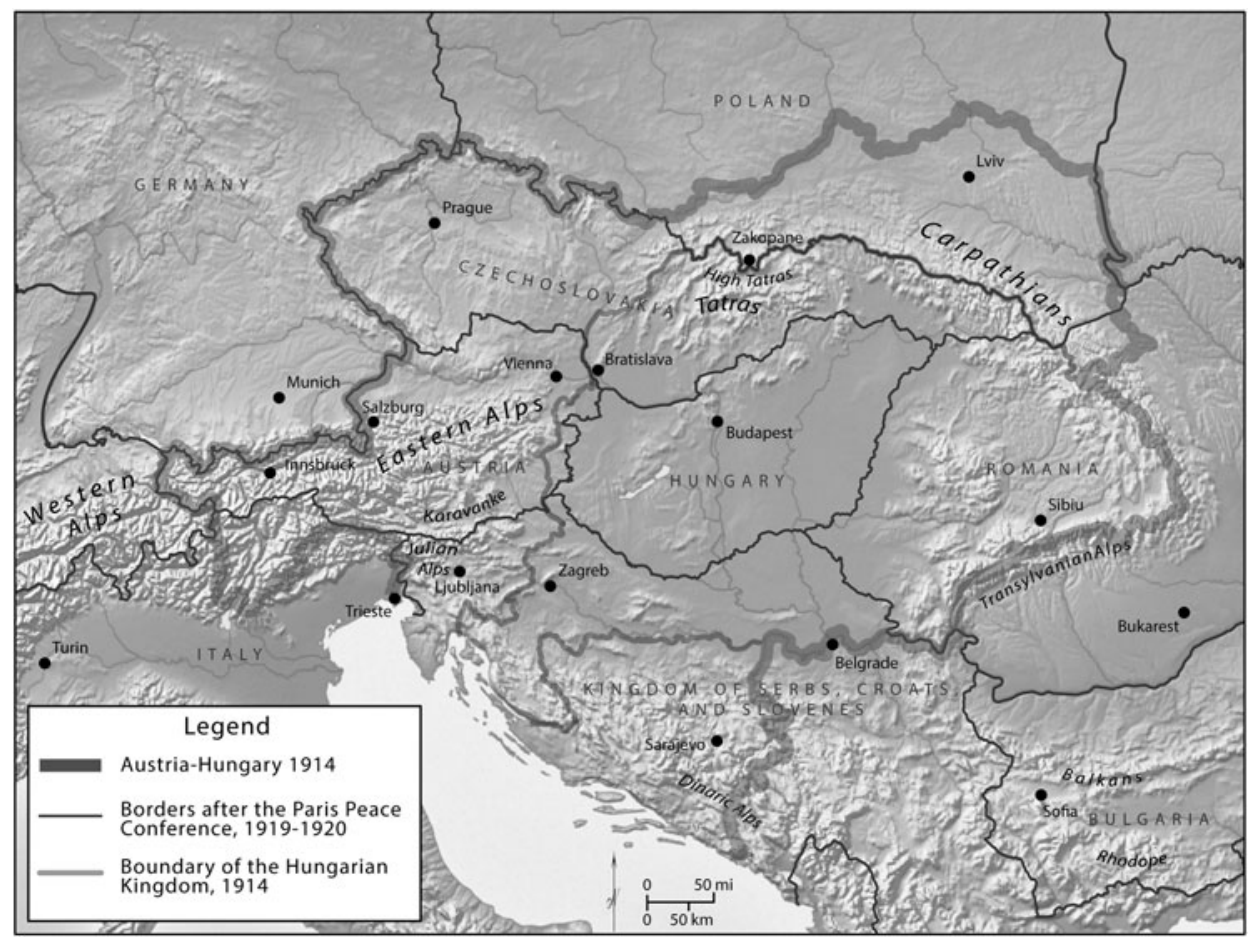

Map 1. Mountains and political boundaries of Central Europe, pre- and post-1919. Created with the support of the Harvard Map Collection.

the meeting rooms than any other topic. ${ }^{27}$ Meanwhile, Central Europe's alpine clubs experienced the repercussions of the territorial reshuffling at full tilt. Austro-Hungary's parts of two large mountain ranges, the Eastern Alps and the Carpathians, were now divided among no fewer than six states: the Carpathians between Czechoslovakia, Poland and Romania, and the Eastern Alps between Italy, Slovenia and Austria (Map 1). ${ }^{28}$

Both in the Eastern Alps and the Carpathians, constitutive local chapters of alpine clubs found themselves cut off not only from their parent organisation, but also from the huts they owned in the mountains. The loss of South Tyrol to Italy amplified nationalist tendencies in the German and Austrian Alpine Club, which also lost huts and local chapters to the newly established Kingdom of Serbs, Croats and Slovenes. ${ }^{29}$ In the context of the complex nation building projects of the interwar period, the Alps and the Carpathians continued to play a central role: as multi-ethnic borderlands, as objects of national symbolism and as landscapes that promised economic revenues at a time in

27 'Le Congrès de l'Alpinisme à Monaco ler Mai-20 Mai 1920', 250.

28 The lower half of the Carpathian arc, the Eastern and Southern Carpathians, in prewar times the natural border between the Habsburg Empire and Romania, became part of the largely expanded Romania after the war. The Western Carpathians were now shared between the re-established Poland and Czechoslovakia, with the old inner-imperial border between Austria and Hungary, which followed the crest of the highest ridge, now functioning as an international border. A small percentage of the Eastern Alps, the Bavarian Alps, belonged to the German Reich - this border did not change.

29 Kurt Scharr, 'Unser Alpenverein will und soll kein politischer Verein sein...' Der 'Deutsche und Österreichische Alpenverein' und der Erste Weltkrieg', Eforum Zeitgeschichte, 1 (2002), 1-26. While some alpine associations gained huts and territory, others lost theirs, or managed to break even after this reshuffling. As most alpine and tourist clubs were organised along ethno-linguistic lines, new governments feared the nationalistic aspirations of minority clubs and demanded severance from the parent organisation or appropriated their property. 
which mass tourism and mountain sports developed into a significant economic force as the popularity of mountaineering and mountain tourism increased. ${ }^{30}$

Not only in the Eastern Alps, but also in the Carpathians, mountain tourism turned from a domestic into a foreign policy issue at a time when the nation state triumphed in East Central Europe. The various tourist associations active in the Carpathians suddenly found themselves caught between the imperatives of competition and the need to cooperate across the new borders that segmented a previously shared space. During Habsburg times, tourists had been able to freely roam across the Tatras, the highest mountain range of the Carpathians. After the war, the new international border necessitated anyone who planned to cross the mountain ridge to carry a passport. The division of the Tatras were not only a nuisance to hikers and mountaineers. On a much larger scale, the Polish and Czechoslovak states embarked on a bitter battle over the demarcation of the shared border in the Silesian Těsín/Cieszyn/Teschen area as well as in the rural Tatra regions of Orava/Orawa and Spiš/Spisz/Zips in the High Tatras. ${ }^{31}$ The Tatra Mountains, which had developed into a symbolic landscape for Polish nationalism already in the nineteenth century, carried particular national significance for the re-established Republic of Poland. ${ }^{32}$ While Zakopane developed into a thriving place of both summer and winter tourist activities in the interwar period, the border disputes meant that the resurrection of Poland had not completed the national project. ${ }^{33}$

The conflict between Poland and Czechoslovakia was eventually solved by the League of Nations in March 1924; the following year the Cracow Protocol solidified the official border line between the two countries. An addendum to this treaty entailed two suggestions for peace projects aimed at reducing competition over the territory: one proposed a zone of relaxed border regimes in which tourists would be allowed free border crossings, the other concerned a cluster of binational parks - an idea that was formulated on the Polish side. While the master project of a binational national park eventually failed - political, economic and identity conflicts could not be overcome - a relaxation of the border regime was achieved by the Polish-Czechoslovak Tourist Convention which entered into force in 1926 and allowed national alpine and tourist club members to cross the borders in particular areas. ${ }^{34}$

The driving force behind the binational park was Walery Goetel, who, as the incident in Chamonix indicated, was both a convinced Polish nationalist and a chief promoter of internationalism who

30 See e.g. Keller, Apostles of the Alps, 152-3.

31 For details see Felix Buttin, 'The Polish-Czechoslovak Conflict over Teschen Silesia (1918-1920): A Case Study', Perspectives, 25 (2005), 63-78; Zygmunt J. Gasiorowski, 'Polish-Czechoslovak Relations, 1918-1922', The Slavonic and East European Review, 35, 84 (1956), 172-93.

32 Patrice M. Dabrowski, “Discovering' the Galician Borderlands: The Case of the Eastern Carpathians', Slavic Review, 64, 2 (2005), 58; Patrice M. Dabrowski, 'Borderland Encounters in the Carpathian Mountains and Their Impact on Identity Formation', in Omer Bartov and Eric D. Weitz, eds., Shatterzone of Empires: Coexistence and Violence in the German, Habsburg, Russian, and Ottoman Borderlands (Bloomington: Indiana University Press, 2013), 195. See also Timothy J. Cooley, Making Music in the Polish Tatras: Tourists, Ethnographers, and Mountain Musicians (Bloomington: Indiana University Press, 2005). Already in the nineteenth century, a famous dispute over the Morskie Oko, a picturesque alpine lake, had pitted the Tatra Society against a Reichs-German landholder who owned property on the Hungarian side. For an interpretation of this conflict see Patrice M. Dabrowski, 'Constructing a Polish Landscape: The Example of the Carpathian Frontier', Austrian History Yearbook, 39 (2008), 61.

33 On the development of Zakopane in the interwar period, see Daniel Stone, 'The Cable Car at Kasprowy Wierch: An Environmental Debate in Interwar Poland', Slavic Review, 64, 3 (2005), 601-24.

34 This larger Carpathian story has been explored in detail by historian Bianca Hoenig, in Geteilte Berge. Hoenig demonstrates that the Tatras became a laboratory of both innovative visions of international cooperation and contested national projects characteristic in the interwar period. For the Tourist Convention see Łukasz Lewkowicz, 'Polsko-czechosłowackie konwencje turystyczne jako przykład współpracy transgranicznej', Sprawy Narodowościowe, 45 (2014), 125-36. The new rule did not apply to all clubs: the German-speaking Beskidenverein Bielsko lost half of its members to the Tatra Society, which had the exclusive rights to distribute the 'Tatra Cards' that served as passport surrogates and provided much broader rights than that Bielsko had to offer. The case demonstrated the limited loyalty of the 'thousands of German tourists', who according to Bielsko were 'forced' to become members of the Tatra Society. The perks of the Polish society were in the end more valuable than loyalty to the defender of 'volksnahe[r] deutsche[r] Kulturarbeit' (German cultural work close to the people). 'Der Beskidenverein Bielitz in der Polenzeit von 1919 bis 1939', nicht verzeichnet/fremde Vereine/Polen, Historisches Alpenarchiv, Innsbruck. 
promoted borders as 'common ground' and national parks as places 'that transcended national identities'. ${ }^{35}$ Furthermore, Goetel demonstrated the fluency with which transnational actors navigated between various roles. Holding academic, political and non-governmental functions, Goetel was professor of geology at the Cracow Mining Academy, served on the state environmental commission and as its representative in the Polish-Czechoslovak border commission and was a leading figure in the Polish Tatra Society. Although his main project, a Polish-Czech binational park in the Tatras, did not succeed in the mid-1920s, he carried his internationalist ideas of cross-border cooperation and dedication to nature protection into the realm of mountaineering. ${ }^{36}$

Besides his involvement in international nature protection, Goetel was also one of the driving forces of the Association of Slavic Tourist Societies (AST), which in 1925 was founded by the Polish Tatra Society, the Slovenian Alpine Club, the Bulgarian Tourist Club and the Czechoslovak Tourist Club. ${ }^{37}$ This organisation was the result of a merger of a pre-war Neo-Slavist idea with the post-war internationalist experience of alpine club officials. Already in the first decade of the twentieth century, a Slavic tourist organisation had been debated, among others, at two Neo-Slavist congresses in Prague (1908) and Sofia (1910). ${ }^{38}$ Neo-Slavism, a movement that emerged as response to Pan-Slavism and promoted Slavic solidarity and equality while rejecting the Pan-Slavist support of Russia as a leader of the Slavic world, was only short-lived. Yet, building on their experience in the immediate interwar period, Goetel, together with counterparts from other Slavic alpine clubs, revived the idea of a joint association. Involved were, among others, the founder of human geography in Czechoslovakia, Viktor Dvorský, who was a main representative at the Paris Peace Conference and also served together with Goetel on the Czech-Polish border commission. Dvorský was not only a nationalist internationalist whose work sought to legitimise the borders of the new state, he was also an active member of the Czechoslovak Tourist Club and argued repeatedly in his work for the function of mountains as the 'spine' of the nation. ${ }^{39}$ In 1925 , after a couple of years preparation, the four societies founded the Association of Slavic Tourist Societies, which was tasked with issues of international cooperation, nature protection, mountaineering as sport and youth development. $^{40}$

\section{From Neo-Slavism to Internationalism}

The vision of the founders of AST did not stop at the borders of the former Habsburg Empire. They had in mind a permanent international association that would be modelled on their regional association. It was meant to be concerned with those questions regarding mountains that needed to be dealt with on an international level and which existing international organisations, such as the Alliance internationale de tourisme (AIT) in Brussels and the Conseil central du tourisme international in

\footnotetext{
35 Wöbse, Weltnaturschutz, 266.

36 For a detailed analysis of why the binational park failed, see Hoenig, Geteilte Berge, 83-111.

37 The names of these associations in their original languages are as follows: Slovenska planinska društva (Slovene Alpine Club), Klub českoslovenkých turistů (Czechoslovak Tourist Club), Bŭlgarsko turistichesko drushtvo (Bulgarian Tourist Association).

38 'Z vseslovansekga kongresa v Sofiji', Glas naroda, 22 Aug. 1910. The Neo-Slavist congresses consisted of meetings of various professional groups. Aside of the alpine and tourist clubs, also journalists and representatives of the Sokol associations met. The latter were a response to the German Turnvereine and succeeded to form short-lived international federation, see Claire E. Nolte, 'All For One! One for All!: The Federation of Slavic Sokols and the Failure of Neo-Slavism', in Pieter M Judson and Marsha L. Rozenblit, eds., Constructing Nationalities in East Central Europe (New York: Berghahn, 2004), 126-40.

39 Michael Fahlbusch, Ingo Haar and Alexander Pinwinkler, Handbuch der völkischen Wissenschaften, Akteure, Netzwerke, Forschungsprogramme (Oldenburg: De Gruyter, 2017), 1262.

40 'Delo za organizacijo slovanskega planinstva', Slovenski Narod, 22 Oct. 1924; 'Zveza slovanskih planinskih društev', Jutro, 20 Sep. 1925. The first assembly took place in Prague in 1926.
} 
Paris, were not able to address. ${ }^{41}$ On behalf of the AST, Goetel thus called upon European alpine clubs and invited them to Zakopane in 1930 for the First International Alpine Congress (although not technically the first, the recount emphasised the beginning of a new era).

For the Polish Tatra Society, the congress at Zakopane was also a prestige project. As Katrin Steffen and Martin Kohlrausch have argued, for experts of the new states of East Central Europe 'there existed an imagined European or even global context of comparison in which the new state had to prove its potential to live up to the demands of modernity'. ${ }^{42}$ Yet the limited attendance of the congress, which presumably was also owed to the remote location, highlights the difficulty of resolving the marginal status of East Central Europeans. Despite Goetel's efforts, the gathering remained a mainly Eastern and Southeastern European affair. Apart from representatives of alpine clubs from Poland, Yugoslavia, Bulgaria and Czechoslovakia, only the French Alpine Club and members of two Swedish organisations were present. The German and Austrian Alpine Club as well as the Italian and British Alpine Club refused to participate, while others expressed interest but did not send delegates. $^{43}$

Despite limited attendance, the congress was remarkable as it concluded with a joint resolution that clearly bore Goetel's signature. A final conference text was drafted which comprised three major areas: the close relationship between the 'ideology of mountain tourism' and nature protection, the importance of national parks (explicitly Goetel's own project in the Tatras) and the practical cooperation among alpine clubs. ${ }^{44}$ The resolution convoked a working group that was tasked with further preparations for the final goal: the establishment of a permanent international organisation that could tackle the above-mentioned themes, including international agreements that would allow cross-border traffic of countries with mountains in border regions, similar to the 1925 Polish-Czechoslovak Tourist Convention. ${ }^{45}$ With few clubs present to fight over posts, the French took over the presidency of the commission, the Tatra Society the secretariat and the Swedes the vice-presidency. ${ }^{46}$

When the Hungarian Tourist Federation (Magyar Turista Egyesület, MTE), an organisation with nationalist roots, announced an international project on its own, the complicated post-Habsburg order brought competition back into the project of alpine internationalism. ${ }^{47}$ In 1920 the principle of national self-determination as executed by the Treaty of Trianon had stripped Hungary of two-thirds of its territory, its access to the sea and all mountainous regions: the Western Carpathians now belonged to Czechoslovakia and Transylvania to Romania. Hungary's new high point reached barely beyond the 1,000 metre mark: Kékestető (1,014 metres) in the North Hungarian Mátra Mountains. Branding Hungary as a tourist destination had already been a complicated side project of nation building before the end of the Habsburg Empire. ${ }^{48}$ In the post-war period,

41 Witold Mileski, 'Międzynarodowa Konferencja Towarzystw Turystyki Górskiej', Wierchy, 8 (1930), 196. For the invitation letter see Polish Tatra Society to DOeAV, 10 July 1929, nicht verzeichnet/fremde Vereine/Polen, Historisches Alpenarchiv, Innsbruck.

42 Steffen and Kohlrausch, 'The Limits and Merits of Internationalism', 726.

43 French interwar relations to Poland and Czechoslovakia were generally close, and France supported the latter as member of the Little Entente. On the level of cultural diplomacy France actively promoted French culture and language in both countries, see Roswitha Reinbothe, 'Languages and Politics of International Scientific Communication', in Martin Kohlrausch, Katrin Steffen and Stefan Wiederkehr, eds., Expert Cultures in Central Eastern Europe: The Internationalization of Knowledge and the Transformation of Nations States since World War I (Osnabrück: Fibre, 2010), 169.

44 'Réunion d'associations de tourisme en montagne à Zakopane', La Montagne, 57 (1931), 59. Goetel presented on nature protection, national parks and their relation to alpinism.

45 Mileski, 'Międzynarodowa Konferencja', 199.

46 'Réunion d'associations de tourisme en montagne à Zakopane', 60.

47 On the nationalist background of the Hungarian Tourist Federation (Magyar Turista Szövetség), founded 1913, see Alexander Vari, 'From Friends of Nature to Tourist-Soldiers: Nation Building and Tourism in Hungary, 1873-1914', in Anne E. Gorsuch and Diane Koenker, eds., Turizm: The Russian and East European Tourist under Capitalism and Socialism (Ithaca: Cornell University Press, 2006), 64-81.

48 See in detail on the post-war and interwar period Alexander Vari, 'From 'Paris of the East' to 'Queen of the Danube': International Models in the Promotion of Budapest Tourism, 1885-1940', in Eric G. E. Zuelow, ed., Touring Beyond 
when the revision of the Trianon treaty became an obsession of Hungarian leaders and the broader population, tourist officials went out of their way to proclaim Hungary as a mountain-loving nation and to stake a territorial claim on mountains, symbolically at least. ${ }^{49} \mathrm{~A}$ year earlier, an international exhibition of mountain art had already showcased the work of three-hundred artists in Budapest inaugurated by the authoritarian Hungarian regent Miklós Horthy de Nagybánya himself. ${ }^{50}$

When the Hungarians announced their intention to host an international alpine congress to be held in conjunction with the first Hungarian National Tourist Exhibition in Budapest in September 1931, fears of Hungarian revisionism were likely evoked. Moreover, hierarchies ruled the Carpathian pecking order. Goetel learned about the Hungarian initiative on a sojourn in Paris. Feeling irritated, he consulted with his French colleagues. It was decided that they would accept the invitation of the Hungarians under one condition: the congress had to be announced as a follow-up to the meeting in Zakopane. ${ }^{51}$ That way, the Polish Tatra Society could claim the status of the original initiator.

The Hungarians accepted. When the Second International Congress took place in Budapest, the list of participants was longer than Zakopane's. Yet, another obstacle to a truly functioning international federation became evident. Europe's largest club, the German and Austrian Alpine Club, had limited interest in the project. The association's indifference was not only owed to the fact that it already controlled much of the territory of the Eastern Alps and had little interest in issues like reciprocal hut access, but also reflected the political radicalisation of the previously politically diverse association. ${ }^{52}$ These sentiments, however, were not openly expressed. Instead, German and Austrian club officials proclaimed that no common alpinist issues existed that warranted an international discussion, and only because of previous assurances delegates were sent to Budapest. ${ }^{53}$ Despite lacking German-Austrian endorsement, the delegates at Zakopane decided to move ahead and meet again in Chamonix, at a meeting organised by the French Alpine Club, with the clear objective of establishing an international organisation of alpine societies and reaching an agreement on a number of technical questions. ${ }^{54}$

\section{The Union Internationale des Associations d'Alpinisme (UIAA)}

The Third International Congress of Alpinism in Chamonix owed its existence to the East Central European clubs which shared the task of leading the secretariat as well as to the French Alpine Club, with which Goetel entertained close relations. While the patronage of the French was indispensable for the initiators to win the support of the other European alpine clubs, East Central European mountaineers were not junior partners in this process. Yet the disinterest of the German and

the Nation: A Transnational Approach to European Tourism History (Farnham: Ashgate, 2011), 103-26; Zsolt Nagy, Great Expectations and Interwar Realities: Cultural Diplomacy in Horthy's Hungary (Budapest: Central European University Press, 2017), 165-228.

49 On Hungarian interwar revisionism as 'civic religion' see Nagy, Great Expectations, 4. For an examination of Hungary's political efforts to revise the Treaty of Trianon, see Miklós Zeidler, Ideas on Territorial Revision in Hungary 1920-1945, trans. Thomas J. DeKornfeld and Helen DeKornfeld (Boulder, CO: Social Sciences Monographs, 2007).

50 'L'Art alpin à Budapest', La Montagne, 57, 230 (1931), 52; 'Ungarische Landesausstellung für Touristik 1931', nicht verzeichnet/fremde Vereine/Ungarn, Historisches Alpenarchiv, Innsbruck. The exhibition presented photos and pictures of Hungarian mountain regions, models of refuges, maps and museum items, and other items related to tourism. Horthy rained Hungary from 1920 to 1944, for more detail see Joseph Rothschild, East Central Europe between the Two World Wars (Seattle: University of Washington Press, 1974), 137-99.

51 Mileski, 'Międzynarodowa Konferencja', 196.

52 For the radicalisation of the German and Austrian Alpine Club in the interwar period, see Keller, Apostles of the Alps; Scharr, 'Deutsche und Österreichische Alpenverein' und der Erste Weltkrieg.'

53 46. Sitzung des Hauptausschusses des D. u. Ö. Alpenvereins, 4-6 Sep. 1931, zu Punkt 2, Hauptauschussprotokolle 19291940. Historisches Alpenarchiv, Innsbruck. The representatives were not authorised to vote for any binding resolutions.

54 In the archives consulted by the author, only little information was to be found on the details of the 1931 Third International Congress in Budapest. 
Austrian Alpine Club and the disdain of the British delegate towards the newly independent countries, which he expressed in his patronising comments in the Alpine Journal, also showed that despite their initiative, the East Central European clubs were still met with suspicion and had to fight for their legitimate place among the Western clubs. The Polish and Czechoslovak delegates, humiliated by the British colleague in the Alpine Journal, protested vehemently against the insults which in their opinion undermined the very foundation on which the UIAA was created. ${ }^{55}$ Their marginalisation was hard to overcome. While the French reaped the benefits of prestige, the Eastern Europeans remained sidelined once again.

The German and Austrian Alpine Club's hesitancy to take part in any internationalist project was not solely owed to the fact that the East Central Europeans had taken the lead. The club also remained reluctant to attend the congress in Chamonix. Initially, the club agreed to attend only if the Swiss and the British Alpine Clubs confirmed their participation. Moreover, they demanded that meetings chaired by a German speaker should be conducted in German. While the first condition was met, the question of languages in transnational organising was always both a political and practical one, and it would remain a challenge for the coming decades. ${ }^{56}$ Confusion arose over the language issue and eventually the German and Austrian Alpine Club sent only one delegate who was not authorised to agree to any binding resolutions. ${ }^{57}$ In addition to being upset about the language issue, the central committee of the German and Austrian Alpine Club had decided that 'the agenda [of the congress] is so extensive and diverse that it cannot be taken seriously - it contradicts the character of a meeting of alpine experts (alpine Sachverständige).$^{58}$ Whether or not this criticism was the main reason for boycotting the congress, the comment reflected the fact that the multidimensionality of alpinism also complicated the formulation of a clear internationalist message. To the associations from the new states, an international organisation promised several opportunities: visibility on international stage, an institutional framework to negotiate relaxed border regimes with state governments and discounts with railway companies and other tourist providers, but also the entrenchment of authority vis-à-vis other tourist and alpine organisations in their own country. As potentially the sole national representative, large associations such as the Polish Tatra Society would be able to act as a quasi-national representative not only on international stage but also on national level. Although the German and Austrian Alpine Club was not the only of its kind in Germany and Austria, it was nonetheless so large and dominating that none of these incentives enticed its leaders.

Yet even without the support of the German and Austrian Alpine Club, the congress reached a major milestone: the creation of the Union internationale des associations d'alpinisme (UIAA), which in the post-war years became known as the International Mountaineering and Climbing Federation. Taking the broadest approach possible, the UIAA was charged with 'the study and solution of all problems related to alpinism in general, mainly from an international perspective', as well as with the organisation of future congresses. ${ }^{59}$ More concretely, the assembly bestowed on the bureau of the UIAA the task of 'tak[ing] steps to assist the movements of climbers in frontier regions' across national

55 Polish Tatra Society to d'Arcis, 24 Jan. 1933, folder 'Pologne/Hongrie', UIAA, Berne.

56 'Alpine Notes: III ${ }^{\mathrm{e}}$ Congrès international d'alpinisme', Alpine Journal, 44 (1932), 341. During the 1932 congress, rumours made the rounds that the Germans had refused to partake because only French, Italian and English would be official languages. The president of the French Alpine Club, Jean Escarra, openly quoted from his statement that German was assigned official status as well, refuting the 'mischievous lie' as a representative of the Alpine Club put it, adding that the absence of the delegates of the German and Austrian Alpine Club 'was sincerely and universally regretted'. See for similar examples Leila J. Rupp, 'The Persistence of Transnational Organizing: The Case of the Homophile Movement', American Historical Review, 116, 4 (2011), 1030.

57 This was despite the efforts of the Hungarians to convince the German and Austrian Alpine Club to send all those delegates who also attended the Budapest Congress. Chair of the Tourist Congress Committee to J. Moriggl, 28 July 1932, nicht verzeichnet/fremde Vereine/Ungarn, Historisches Alpenarchiv, Innsbruck.

58 47. Sitzung des Hauptausschusses des D. u. Ö. Alpenvereins, 7-8 May 1932, zu Punkt 26, Hauptauschussprotokolle 19291940, Historisches Alpenarchiv, Innsbruck.

59 Resolutions of the Third International Congress of Alpinism, 27 Aug. 1932, folder, Assemblée générale’ 1932-1935, UIAA, Berne. 
borders. As Pierre Bossus, a future president of the UIAA, wrote in a brief institutional history, 'the clubs expressed it as their wish that they henceforth be the beneficiaries of an evolutionary process that would eventually eliminate the problems of national frontiers'. ${ }^{60}$ The alpine clubs that created the UIAA represented an internationalism that was pragmatic and motivated by their self-interest in gaining access to mountains. At the same time, the belief in an 'evolutionary process' of a withering away of national frontiers carried undertones of pacifist utopianism, given that the 1930s were marked by nation-centred agendas. ${ }^{61}$

Yet the experiment of alpine internationalism could not be fully successful without the cooperation of the mighty German and Austrian Alpine Club. Neither could it be fully legitimised without the cooperation of Britain's prestigious Alpine Club. In search of international recognition, the promoters of alpine internationalism hence embarked on a process of alpine appeasement while trying to win the alpine clubs of the great powers for their cause. It would however take until the post-war period until a democratised German Alpine Club, together with its by then separated Austrian counterpart, would join the UIAA. Although the organisation achieved very little in the interwar period, East Central European internationalism paid off in the post-war period. Interwar internationalists established connections that were resilient enough to even endure the political bifurcation of the Cold War era. Despite the limits imposed by the Cold War, East Central European countries remained active members in the UIAA apart from a brief period in the early 1950s. Their efforts improved not only their position among the established alpine clubs on the level of international cooperation but UIAA membership also allowed Eastern European mountaineers to maintain contacts across the Iron Curtain, take part in international climbing exchanges and occasionally serve as a mediator between Western climbers and Soviet mountaineering officials. ${ }^{62}$ Until today, the concerns that initiated the founding of the Slavic Association of Tourist Organisations in the 1920s - international cooperation, environmental protection, mountaineering and sport, as well as youth development - form the core tasks of the UIAA. ${ }^{63}$

\section{Making Europe Work}

Exploring East Central European contributions to international history in the interwar period brings to light an interconnected Europe which on a political level might have been dictated by the Great Powers, but on a cultural and social level allowed 'boutique' internationalists to promote their own agenda and change the quality and goals of internationalism. The International Mountaineering and Climbing Federation, as the UIAA later became known, was a project originating in the territorial circumstances of post-Habsburg Central Europe. Yet the internationalism that developed in the Carpathians was a product not of a merely rhetorical peace project. Rather it was a co-product of antagonist forces such as bilateral relations with clubs in neighbouring countries which oscillated between competition and Pan-Slavic solidarity as well as Hungarian revisionism. Although historians have lamented that the geographical region lacked both the uniformity to be a meaningful historical concept as well as regional solidarity, tourism in fact necessitated collaboration beyond borders: divisions brought entanglement.

60 Pierre Bossus, Les cinquante premières années de l'Union internationale des associations d'alpinisme (Geneva: UIAA, 1982), 73.

61 For internationalist efforts in the same time period, see Iriye, Global Community, 34-35.

62 For details see Carolin F. Roeder, 'European Mountaineers between East and West: A Transnational History of Alpinism in the Long Twentieth Century', Ph.D. thesis, Harvard University, 2017. On internationalism and East Central Europe's place in the wider world during the Cold War, see e.g. Kott, 'Cold War Internationalism'; Patryk Babiracki and Austin Jersild, eds., Socialist Internationalism in the Cold War: Exploring the Second World (Cham: Springer International, 2016); 'Special Issue: Beyond the Iron Curtain: Eastern Europe and the Global Cold War', Slavic Review 77, 3 (2018); Michel Christian, Sandrine Kott and Ondrej Matejka, eds., Planning in Cold War Europe, Competition, Cooperation, Circulations (1950s-1970s) (Oldenburg: De Gruyter, 2018).

63 For the current mission statement, see https://www.theuiaa.org/about (last visited 1 Sept. 2018). 
The wish to eliminate national frontiers was not a disguised call for reinstating the pre-war order. East Central European internationalism was a response to the dissolution of the Habsburg Empire, not an attempt to recreate it. As Holly Case has argued, 'the interwar period was one of trying to make new states work, rather than about joining another European empire. ${ }^{64}$ Mountain tourism was intimately linked to questions of territory, infrastructure and cross-border travel, thus the concerns of the alpine clubs mirrored the occupations of the state more closely than the developments that led to the creation of other international sport organisations in the interwar period. For East Central European alpine clubs, 'making Europe work' meant coping with new borders, resolving legal fights over property, securing access to formerly shared space and taking care of club chapters now located in a foreign country. The step from regional cooperation to a permanent international organisation was motivated by the wish to take part in a larger re-imagination of Europe - a Europe that was formed by sovereign nation states which were treated as equals regardless of their size.

Acknowledgments. Research for this article was partially funded by the Minda de Gunzburg Center for European Studies at Harvard. I am grateful to Alison Frank, Bianca Hoenig, Erin Hutchinson and the anonymous reviewers for their helpful comments and feedback.

${ }^{64}$ Holly Case, 'Being European: East and West', in Jeffrey T. Checkel and Peter J. Katzenstein, eds., European Identity (Cambridge: Cambridge University Press, 2009), 122.

Cite this article: Roeder CF (2020). From Neo-Slavism to Internationalism: Interwar Central Europe and the Search for the Lost Mountains. Contemporary European History 29, 16-29. https://doi.org/10.1017/S0960777319000171 